\title{
Last Resort: European Central Bank's Permanent Engagement in Tackling Foreign Exchange Liquidity Disruptions in the Euro Area Banking System*
}

\author{
Gábor Dávid Kiss - Gábor Zoltán Tanács - Edit Lippai-Makra - Tamás Rácz
}

Prior to the outbreak of the global financial crisis, the international interbank market for key currencies narrowed and market participants faced foreign currency liquidity shocks more frequently. The US Federal Reserve was first to address the problem with a series of currency swap lines concluded with other major central banks after December 2007. Although these measures were initially considered temporary, they are still present today in the practices of the leading central banks, and thus of the European Central Bank. Inter central bank currency swap lines facilitate, if necessary, the provision of an adequate level of foreign currency liquidity to the banking system as a kind of "last resort", on more favourable terms than market conditions. In our study, we examined the evolution of the demand for foreign currency liquidity provided by the European Central Bank to the euro area banking system between 2007 and 2019, on quarterly data and using vector autoregression. We found that the allocation of dollar-denominated foreign currency resources through the ECB's tenders increases the most when the banking system is unable to raise international funds on a market basis, when dollar market tensions rise or when their return on assets ratios deteriorate.

Journal of Economic Literature (JEL) codes: E52, E58, E44, C22

Key words: last resort, foreign exchange liquidity, foreign exchange swap, repo, tender, banking system, unconventional monetary policy, ECB, VAR

\footnotetext{
* The papers in this issue contain the views of the authors which are not necessarily the same as the official views of the Magyar Nemzeti Bank.

Gábor Dávid Kiss is an Associate Professor at the University of Szeged, Faculty of Economics and Business Administration. Email: kiss.gabor.david@eco.u-szeged.hu

Gábor Zoltán Tanács is a Master of Finance Student at the Faculty of Economics of the University of Szeged. Email: tanacsgabor1995@gmail.com

Edit Lippai-Makra is an Assistant Lecturer at the Faculty of Economics of the University of Szeged.

Email: makra.edit@eco.u-szeged.hu

Tamás Rácz is a PhD-Student Lecturer at the Faculty of Economics of the University of Szeged.

Email: racz.tamas@eco.u-szeged.hu
}

The research was supported by the project EFOP-3.6.2-16-2017-00007, Aspects of the Development of a Smart, Sustainable and Inclusive Society: Social, Technological, Innovation Networks in Employment and the Digital Economy. The project is supported by the European Union, co-financed by the European Social Fund and the Hungarian budget.

The Hungarian manuscript was received on 23 April 2020.

DOI: http://doi.org/10.33893/FER.19.4.83106 


\section{Introduction}

Fundraising and lending denominated in foreign currency has become significant in the banking systems of developed countries since the 1960s. First US dollar deposits appeared under the liabilities of Western European credit institutions, followed by petrodollars from oil-exporting countries (Madura 2008). At the same time, we can now talk about institutional investors in this field who have appeared with tax optimisation intentions, and we can also refer to deposit placements from capital flight (Kiss - Ampah 2018). We can see that both international trade and the institutional weaknesses of developing countries are creating excess foreign exchange liquidity in developed markets, which is then allocated: today, the dollar accounts for approximately 60 per cent of foreign exchange reserves, the international bond market and private lending, the euro 20 per cent, while the share of yen and renminbi is below 5 per cent (ECB 2019). However, disruptions in the network structure of the international interbank market ${ }^{1}$ can lead to a serious lack of liquidity.

During the global financial crisis of 2007-2008, the flow of international liquid capital suddenly narrowed or even stopped suddenly in some channels, which made financing on market terms difficult even if the public debt or banking system of the given country had not had any problems before. While the resources of the International Monetary Fund (IMF) are typically used to address national nearbankruptcy situations, and during the European sovereign debt crisis the bank bailout largely relied on lending via the European Stability Mechanism (ESM) and its predecessors, the conditions of providing short-term foreign currency liquidity was less institutionalised. These foreign currency liquidity needs typically stem from the turmoil on international financial markets, thus they can emerge quickly and vary widely in magnitude. In our study, we will explain the background to this ad hoc foreign currency liquidity provision through the example of the European Central Bank (ECB), making special reference to currency swap lines established by major central banks and regionally. A currency swap can be used extensively, inter alia, for liquidity management, risk hedging and short-term yield speculation (Mák - Páles 2009), but in the course of our work we analyse these transactions solely on the basis of the central banks' international function to acquire foreign currency liquidity. To assess changes in foreign exchange exposure, it is also worth separating currency swaps (where the foreign exchange exposure changes) from repurchase transactions (where the exposure does not change) conducted with foreign currency-denominated securities collateral - however, liquid assets are required in both cases.

\footnotetext{
${ }^{1}$ See, for example: The results of Ananda et al. (2012); Allen - Babus (2009) on the topology changes of US interbank markets, or Berlinger et al. (2011); Banai et al. (2015) on that of the Hungarian.
} 
Although it seemed at first that the European banking system would only turn to the ECB for foreign exchange liquidity on a temporary basis, practice shows that this instrument has had to be used for almost 13 years, and the COVID-19 crisis in 2020 has further increased the amount of capital allocated. In the course of our work therefore, we examine the change in the capital allocated by the ECB in US dollar-denominated tenders with euro area credit institutions between 2007 and 2019 , using a vector autoregression model. To this end, we analysed the ratio of the non-euro-area non-euro denominated liabilities of the banking system to the balance sheet total, the dollar market tensions indicated by the EUR-USD basis swap, the banking system's return on assets and the structural changes on the asset side of the ECB's balance sheet. To establish the foundations of the theoretical model, we first present the evolution of currency swap lines between central banks during the period under review, as well as the relevant practice of the ECB. Next, we describe the data and methodology used, and finally, we evaluate the obtained results in light of the intuitions formulated for the theoretical model. We found that, although financing costs did not, the other variables had a significant impact even in the medium term on euro area credit institutions turning to the ECB when they needed foreign exchange liquidity.

\section{Theoretical background}

Prior to the global financial crisis, between 2003 and 2007 the aggregate loan-todeposit ratio of euro area banks was above 100 per cent, and financed increasingly from money market funds in addition to significant bond holdings (ECB 2008). This chapter summarises the central bank swap lines and the changes to the euro area banking system that have led to an appreciation of the ECB's role in providing stable foreign currency liquidity to the banking system as a direct consequence of the above situation. The fact this role has remained and has accompanied the functioning of the ECB to this day is also reflected in the theoretical model developed in this study.

\subsection{Swap lines between central banks}

In the toolbox of unconventional monetary policy that spread following the 20072008 global financial crisis, in addition to the bond market's function of "market maker of last resort", the instrument of foreign currency funding was added to the traditional "lender of last resort" 2 function of central banks (typically for short maturities, O/N and 3-month) (BIS 2011; Seghezza 2018; Ács 2011). This is because a central bank may also decide not to invest an existing foreign currency resource in a foreign asset, but to continue lending to national credit institutions, which

\footnotetext{
${ }^{2}$ Although the term "lender of last resort" is used in international literature, due to the mass application of repo transactions, this means funding in a broader sense.
} 
would, however, result in a decrease in foreign exchange reserves. Since foreign exchange reserves must meet the expectations set by credit rating agencies and other stakeholders (e.g., Guidotti-Greenspan and M2 rules), it seemed appropriate to expand the range of foreign exchange sources (Obstfeld et al. 2009). This can be realised by issuing bonds in foreign currency (which in turn are considered government securities), collecting deposits in foreign currency, or borrowing (from another central bank or the Bank for International Settlements), but this is more difficult to achieve in a market with a lack of liquidity. In this case, it is possible to borrow within an institutionalised framework (IMF or Regional Financing Agreements) or to resort to alternative, ad-hoc foreign exchange resources (interbank swap and repo lines) (Antal - Gereben 2011).

In a currency swap between central banks, the two central banks lend to the other party in their own currency, thus taking both spot and forward positions ${ }^{3}$, where the exchange rate difference between the two positions is the swap point. A swap line can provide access to foreign currency liquidity in a decentralised manner, which seems faster and more flexible compared to the terms of an institutionalised (e.g. IMF) loan ${ }^{4}$. As a result, however, currency swap lines can have a number of pitfalls: their creation requires a counterparty central bank with opposing foreign exchange demand; at the end of the line, the counterparty may decide to terminate the continuation; central banks issuing key currencies are free to choose between potential counterparties and there is a lack of collateral against default ${ }^{5}$ (Destais 2016).

Inter-central bank ad-hoc currency swap lines have appeared on international markets since the 1920s, typically with a maturity of 3 months, which the US Federal Reserve (Fed) raised to a higher level from 1962 by establishing the network of swap lines, also including Western central banks and the BIS, to address imbalances arising from the Triffin paradox ${ }^{6}$ (Bordo et al. 2015). At the focus of this was the dollar as the gold-backed world money of that time. From the post-Bretton Woods era we can mention the 2001 dollar swap line, where now the ECB appeared as the issuer of the newly created euro.

The transitional (6-month) inter-central bank dollar swap line, initially with four leading central banks (Canadian, British, Swiss and the ECB), established in

\footnotetext{
${ }^{3}$ The market can deviate significantly from the level justified by the covered interest rate parity due to stress, as stated by Csávás - Szabó (2010). Brophy et al. (2019) added to this the additional biases resulting from central bank bond purchase programs.

${ }^{4}$ In particular due to its budgetary and economic policy implications, which are completely missing from a swap line.

${ }^{5}$ Although in this case it is also possible to conclude a repo agreement.

${ }^{6}$ The dollar was a national currency and a key global currency at the same time, so while the latter requires the US balance of payments to be in a deficit to satisfy international dollar requirements (resulting in an outflow of gold reserves in the long run), the short-term domestic economic policy objectives might run counter to this.
} 
December 2007, elevated the Fed to the position of international lender of last resort. The other central banks of the G10 countries joined this in March 2008, and subsequently the Central Bank of Japan in September 2008. The agreements were regularly renewed every six months, while on 1 February 2010, the international financial markets apparently no longer required this type of channel, therefore the central banks considered the cooperation closed ${ }^{7}$. However, this kind of optimism did not prove lasting, as this type of transitional dollar swap line had to be re-established in May $2010^{8}$ (Figure 1). Following a series of renewals to the cooperation, the counterparties reached a point in December 2011 where they were able to swap not only in dollars but also in their own currencies ${ }^{9}$ (i.e. in Canadian dollars, pounds, yen, Swiss francs and euros, in addition to the US dollar). By the end of October 2013, it became clear to the parties that the "transitional" swap lines, which had been ongoing for almost six years, could not yet be cancelled for a long time, despite the temporary easing of foreign exchange liquidity needs, thus the six founding central banks entered into a standing arrangement ${ }^{10}$.

\section{Figure 1}

Value of swap lines entered into by the Fed with central banks (weekly average, million dollars, plotted on a logarithmic scale)

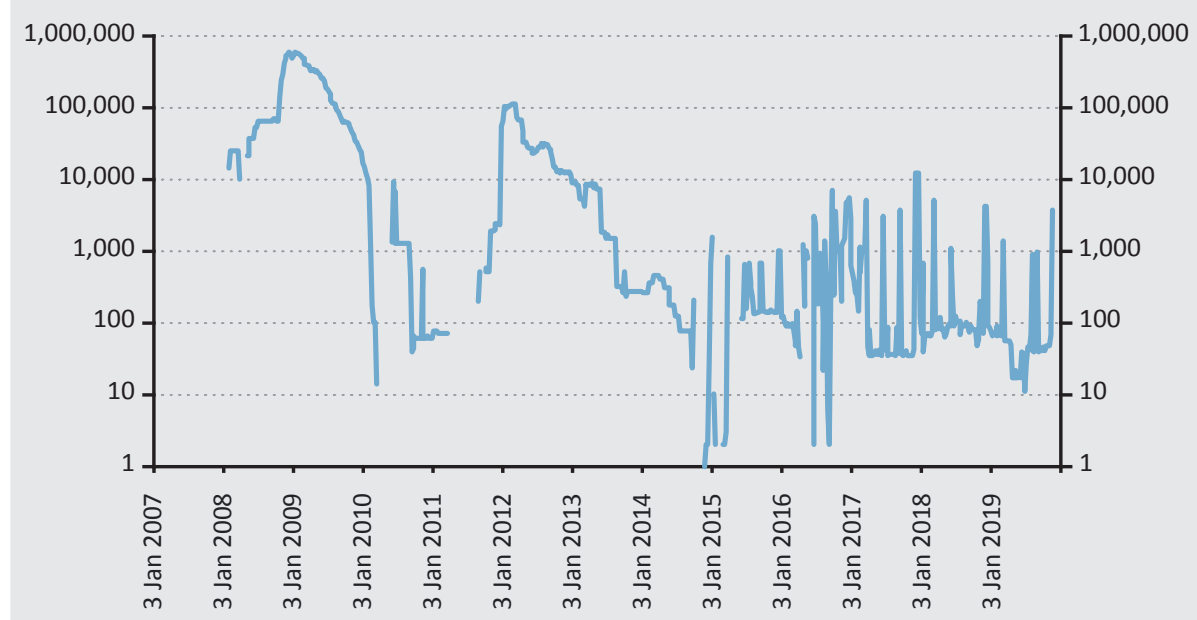

${ }^{7}$ https://www.ecb.europa.eu/press/pr/date/2007/html/pr071212.en.html

${ }^{8} \mathrm{https}: / /$ www.snb.ch/en/mmr/reference/pre_20100510_3/source/pre_20100510_3.en.pdf

${ }^{9}$ https://www.ecb.europa.eu/press/pr/date/2011/html/pr111130.en.ht'ml

${ }^{10} \mathrm{http}: / /$ www.ecb.europa.eu/press/pr/date/2013/html/pr131031.en.html 
Under the agreements, the liquidity thus acquired was lent by central banks through various channels: the ECB typically conducted repo tenders with $\mathrm{O} / \mathrm{N}$, 1-week, 1-month and 3-month maturities. The severity of the market problem is well illustrated by the fact that the ECB still carries out lending in US dollars to this day, meaning that between December 2007 and March 2020, the purely marketbased international financing did not fully recover in reserve currencies either! Thus, the "last resort" function has now verifiably been added to the tasks of the leading central banks, also in ensuring the adequate foreign currency liquidity of the banking system.

In the case of a central bank issuing a reserve currency, it is expected that it will easily be able to find a counterparty for a currency swap as it provides loans to the other party in a foreign currency that can be lent domestically. And if the liquidity needs of the banking sector would not absorb this type of liquidity, it can still replenish its international reserves. The individual regional interbank swap lines add further nuances to the situation: in October 2008, the Fed entered into similar agreements with the central banks of Brazil, Mexico, South Korea and Singapore (Seghezza 2018). Similarly, the Scandinavian (Danish, Norwegian and Swedish) central banks were able to obtain dollar liquidity. This is interesting because the very same central banks concluded euro swap lines with the ECB too in autumn 2008, while from May 2008 they entered into euro swap lines with the central bank of Iceland, then of Latvia in December 2008, and finally from May 2009 with the Estonian central bank. Subsequently, this kind of solidarity was embodied in the conclusion of a cooperation agreement ${ }^{11}$ in August 2010, which institutionalised cross-border financial stability, crisis management and bank consolidation. The rationale behind the Nordic Baltic Stability Group was the Baltic dominance of Swedish banks, and its success is clearly shown by the accession of the Baltic countries to the euro area and the renewal of cooperation in $2018^{12}$.

The ECB also entered into euro-pound and euro-Swiss franc swap lines between 2008 and 2010. However, with respect to non-euro area Member States (e.g. Poland, Hungary and Latvia), it mainly gave priority to covered repurchase agreements (by accepting euro-denominated bonds) (Allen - Moessner 2010). By contrast, the Swiss and Polish central banks entered into a Swiss franc-zloty swap line in 2012. We can state that in the case of small, emerging, open economies, it was still best to address capital flow disruptions through the institutional instrument of conditional lending, the IMF loan - even if Poland did not use the flexible credit line made available to it between 2009 and 2017. According to the results of Obstfeld et al. (2009), the inadequacy of foreign exchange reserves relative to $M 2$ in emerging

\footnotetext{
${ }^{11}$ https://www.cb.is/publications/news/news/2010/08/17/Nordic-and-Baltic-Ministries--Central-Banks-andSupervisory-Authorities-sign-Agreement-on-Financial-Stability-/

12 https://www.fi.se/en/published/news/2018/new-nordic-baltic-memorandum-of-understanding/
} 
countries well explains the devaluation of currencies, and the fact that the swap lines implemented can be considered rather symbolic in terms of their magnitude is also attributable to this.

Contrary to the above, the motivation for the renminbi swap lines entered into by the Chinese central bank after 2008 was not a central bank response to the shock manifested in the availability of an already fully used reserve currency, but rather another attempt to resolve the Triffin dilemma (Seghezza 2018). Namely, based on this, the renminbi liquidity received during the agreement should appear among the liabilities then among the assets of the banking system, thus gaining an increasing role in the line of international means of payment (Engelberth - Sági 2017).

Global dollar funding depends on the operation of both US and non-US (typically Japanese, UK, Canadian, French, German and Dutch) banks. In the case of Japanese banks, while Aldasoro et al. (2019) observed a significant increase, a near doubling, of dollar-denominated assets between 2007 and 2017 as traditional commercial banking activity improved, in the case of European banks the asset and liability sides more than halved during this time and short-term arbitrage transactions began to gain priority. Dollar funding for non-US global banks comes primarily through US money market funds, which used repo-type channels to a lesser extent and nonrepo type ${ }^{13}$ channels to a greater extent in an increasingly concentrated market during the 2010s. For these funds, the Fed's overnight reverse repo instrument represents the safest investment alternative in addition to short-term government bonds, thus a position with non-US banks should provide a premium above this.

\subsection{ECB's foreign currency lending}

In the autumn of 2007, the European banking system not only had significant leverage on its US counterpart, but also had significant US exposures on the asset side (Pelle - Végh 2019). Companies with international foreign currency income, other actors with domestic foreign currency income on the asset side of the bank balance sheet, as well as the ratio of foreign currency resources all determine the extent of any currency mismatch in the case of a credit institution (Destais 2016; Mák - Páles 2009). The liabilities side includes foreign currency deposits of domestic or foreign institutional investors, as well as short-term bonds issued in foreign currency or repo transactions, which require frequent renewal due to the maturity transformation.

\footnotetext{
${ }^{13}$ Short-term securities, such as: commercial paper, certificates of deposit, asset backed commercial papers.
} 
The renewal of foreign currency liquidity can be particularly problematic when the weight of foreign currency resources is relatively high within the balance sheet $\left(\frac{L_{n E Z, t}}{T L_{t}}>0\right)$. Páles et al. (2010), for example, derives the change in the derivative position with non-residents from the net borrowing requirement as the difference between non-debt-generating capital inflows, forint and foreign currency debt, the actual open position of the banking system and the derivative position with the domestic private sector. Although the use of foreign currency resources is typically mentioned in literature when describing the inconsistency of foreign currency devaluations in developing countries (see Frankel 2011 for example), as mentioned in the previous subsection, a currency mismatch can cause a problem in developed markets too.

According to ${ }^{14}$ Destais (2016), since the collateral behind an inter-central bank swap line is created by the quality of credit institution use and the ability to repay, this credibility is ultimately a macroprudential issue (Baker 2013). The rate of return on assets $\left(R O A_{t}\right)$ can thus have a direct effect on the desirability of a bank in the international interbank market if it wants to acquire foreign currency liquidity. In the case of rational market participants, a deteriorating $R O A$ could push the market towards central bank foreign currency auctions. This kind of "aversion" may also stem from tensions in the international dollar market, which can be captured most effectively by the change in the basis swap between the two key currencies, the dollar and the euro $\left(b S_{3 M, \frac{E U R}{U S D}}\right)$, after Kick et al. (2018) demonstrated the effective pass-through of the US financing environment into the euro area. In the course of their work, the effects of the Fed's unconventional actions on dollar financing were felt by German banks. Based on Figure 2, we can conclude that the ECB has to conduct foreign currency repo tenders primarily in US dollars, while the appearance of the Swiss franc has proven to be episodic. From the perspective of our work, therefore, we will focus on the change in the dollar liquidity $\left(K_{U S D, t}\right)$ provided by the ECB in tenders.

${ }^{14}$ In the case of market-based swaps there is a margin requirement; the value of margin call for the total net swap portfolio maturing in foreign currency at $i$ times in relation to the $V O L_{i}$ contract not yet expired:

$$
M C_{t}=\sum_{i=0}^{N_{t}} \frac{S_{t}-S_{0, i}}{S_{t}} \cdot V O L_{i},
$$

where $S_{0, i}$ is the spot exchange rate of each $i$ transaction at the time of conclusion, $s_{t}$ is the spot exchange rate, $N_{t}$ is the number of transactions not expired at the given time (Páles et al. 2010). 


\section{Figure 2 \\ Developments in US dollar and Swiss franc liquidity lent in the ECB's repo tenders between 2007 and 2020 ( $€$ million)}

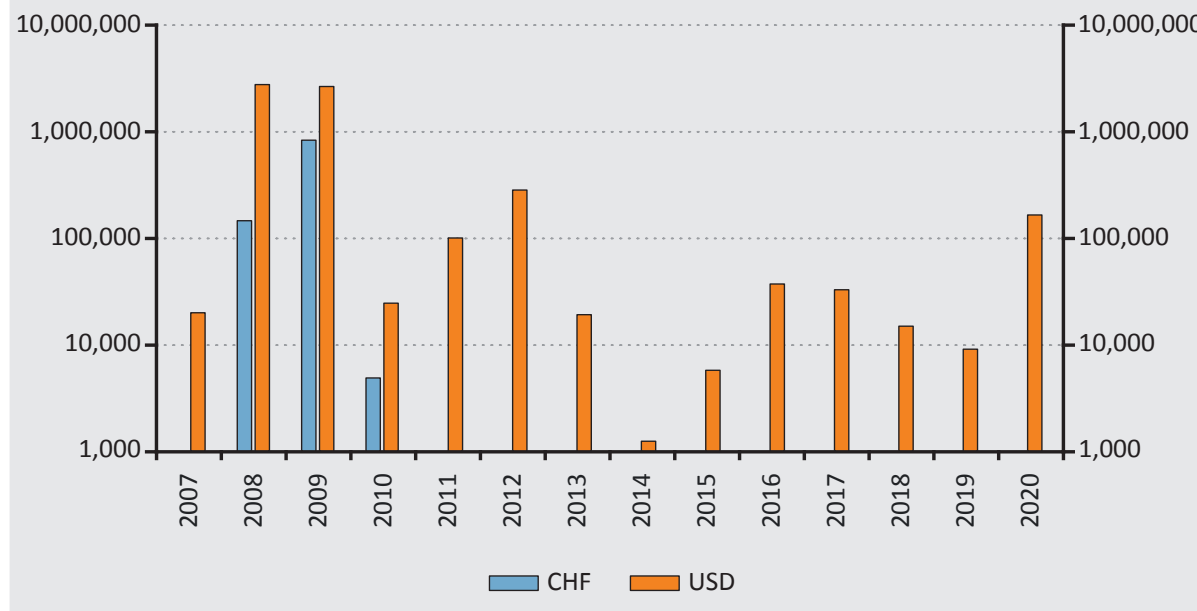

Source: Plotted based on ECB's data

The issue of foreign currency liquidity provided by the ECB within the euro area is not a much-studied area in literature; the analysis of cross-border lending in a reserve currency is a much more popular topic. Alvarez et al. (2017) described the phasing out of longer maturities for the various interbank foreign currency swap lines (1-week, 1-month and 3-month) following the passing of global crises, emphasising that the ECB provides dollar liquidity to the euro area banking system mainly through repo tenders against adequate collateral. So in the latter case we cannot talk about a change in foreign currency exposure, whereas in the case of a foreign currency swap, we can. However, market demand for the latter has dropped significantly since 2009 .

Takáts - Temesvary (2020) also focuses primarily on the monetary policy transmission effects of cross-border foreign currency lending, emphasising that monetary policy impacts on cross-border foreign currency lending even if neither the lender nor the debtor is resident. On the other hand, the interbank role of this type of lending is negligible, basically non-bank actors have emerged as debtors. Similarly to them, Avdjiev et al. (2016) examined cross-border lending in euros, incidentally finding a 30 per cent share of the dollar in the euro area in this area. In their model, in addition to variables describing lending, the exchange rate was also present in addition to banks' share prices and sovereign risk. In their work, they found that, in addition to the international dollar-denominated lending network, there is also a more modest, but euro-denominated lending network that is gaining momentum due to the ECB's unconventional monetary policy. However, by 
specifically examining the lending of European banks in dollars, Ivashina et al. (2015) found that the increase in lending in euros was accompanied by a deterioration in the quality of the loans they provided. Parallel to this, they also highlight the narrowing of traditional market channels, which has made access to dollar liquidity expensive. Albrizio et al. (2020) originates the decline in cross-border dollar lending from the monetary shock resulting from the exogenous tightening of the Fed. In addition, Aizenman et al. (2020) and Seghezza (2018) thoroughly examined the relationship between the composition and relative size of international foreign currency reserves and macro variables, looking at the impact of swap lines separately, however, the authors do not analyse the specific demand set by credit institutions themselves vis-à-vis their central bank with respect to the motivation to acquire foreign currency liquidity.

\subsection{Theoretical model}

In summarising the literature, we found that the motivation for swap lines between central banks was that commercial banks had difficulty accessing foreign currency funding in international interbank markets. To satisfy this hunger for foreign currency liquidity, central banks provided liquidity obtained through international swap lines through tenders for their own banking system. This is the ratio of dollar liquidity provided in a given quarter to total lending measured over the entire period, denoted by $\frac{K_{U S D, t}}{\sum K_{U S D}}$ in our model as the result variable. The ratio of non-euroarea liabilities of euro area credit institutions to total assets $\left(\frac{L_{n E Z, t}}{T L_{t}}\right)$ characterises the external exposure of the banking system well. As an indicator of dollar market tensions, we use the 3-month EUR-USD basis $\operatorname{swap}^{15}\left(b S_{\left.3 M, \frac{E U R}{U S D}\right)}\right)$ the negative value of which indicates an increase in funding in dollars. The profitability of the credit institutions involved was included in the model using return on assets $\left(R O A_{t}\right)$. The ECB's securities market $\left(S_{t}\right)$ and lending $\left(L_{t}\right)$ practices that are becoming active were measured by the $\left(\frac{L_{t}+S_{t}}{F X_{t}}\right)$ ratio measuring the restructuring of the central bank's balance sheet and apportioning with the international reserve $\left(F X_{t}\right)$.

The fractures in capital flows due to changes in business cycles were represented by the dummy variable of the recession $\left(d_{E Z, t, t}\right)$ emerging in the euro area. On the other hand, to ensure the normal distribution of the error terms of the regressions, it was advisable to include a dummy variable $\left(d_{\text {out }, t}\right)$ representing the fall of dollar liquidity to zero.

${ }^{15}$ Currency Basis Swap: 3M EURIBOR/3M USD LIBOR, ICAP 
In the course of our work, we examine the above variables using the following theoretical model between 2007 Q4 and 2019 Q4 ( $t=1: 49)$ :

$$
\Delta \frac{K_{U S D, t}}{\sum K_{U S D}}=\omega+\beta_{1} \Delta \frac{L_{n E Z, t}}{T L_{t}}+\beta_{2} \Delta \frac{b S_{3 M, \frac{E U R}{U S D}, t}}{100}+\beta_{3} \Delta R O A_{t}+\beta_{4} \Delta \frac{L_{t}+S_{t}}{F X_{t}}+\beta_{5} d_{E Z r, t}+\beta_{6} d_{\text {out }, t}
$$

In this model, we can formulate the following intuitive expectations for each coefficient: increasing external exposure could mean that credit institutions are able to raise funds on a market basis and are therefore expected to make less use of the ECB's dollar liquidity allocation tenders, thus $\beta_{1}<0$ is expected. The declining level of the foreign currency swap reflects the banks' increasing hunger for liquidity, which encourages the ECB to increase its dollar liquidity lending $\left(\beta_{2}<0\right)$. If the ROA falls, it is expected that banks will rely much more on a form of financing that is more favourable than the market, thus we expect a $\left(\beta_{3}<0\right)$ negative coefficient here. The increasingly serious credit and securities market interventions by the central bank indicates the liquidity allocation in foreign currency $\left(\beta_{4}>0\right)$. The appearance of these expectations can also be expected at the level of impulse response functions and variance decompositions. The theoretical model was tested using Eviews 11 software.

\section{Data and methodology}

\subsection{Data}

The dollar-denominated swap lines of leading central banks have gained major traction since December 2007, thus the sample under review covers 49 quarters between the last quarters of 2007 and 2019. The sources of the data used were as follows: information on lending in foreign currency tenders was downloaded from the ECB's database listing open market operations denominated in foreign currency ${ }^{16}$, and then data on individual tenders were aggregated to a quarterly basis as described in the theoretical model subsection. Balance sheet and ROA data for euro area credit institutions were downloaded from the relevant statistical database of the $\mathrm{ECB}^{17}$. The foreign currency basis swap time series was downloaded from the Refinitiv Eikon database. The dummy variable, which symbolises the recession quarters of the euro area, was created based on a database of the European Commission $^{18}$.

\footnotetext{
${ }^{16}$ https://www.ecb.europa.eu/mopo/implement/omo/html/top_history.en.html

${ }^{17} \mathrm{http}: / /$ sdw.ecb.europa.eu/browse.do?node=9691316

${ }^{18} \mathrm{https}$ ://ec.europa.eu/eurostat/cache/bcc/bcc.html
} 


\section{Figure 3 \\ Values of monetary policy variables included in the model}

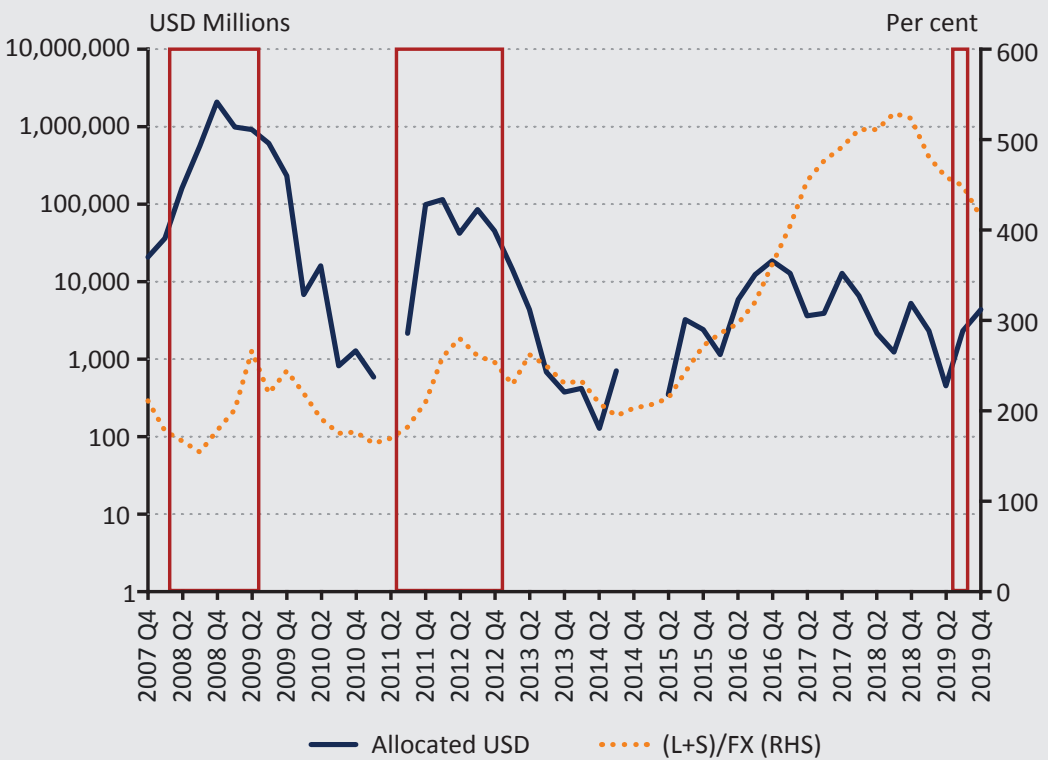

Note: Rectangles represent recession quarters.

Source: Plotted based on ECB's data

Figure 3 shows that the peak in allocated dollar liquidity fell predominantly on 2008 and 2010 followed by a second wave from late 2011 to mid-2014, and then stabilised at a low level after 2015. Parallel to this, the ECB's lending and securities purchasing activity increased markedly in the first half of 2010, but it is clearly visible how the $\frac{L_{t}+S_{t}}{F X_{t}}$ - indicator started to increase significantly in the first half of the decade following the QE announcement.

The drop in the value of return on assets shown in Figure 4 closely followed the fluctuations in economic cycles, while the ratio of the banking sector's external resources to total assets declined steadily over the period under review, from an initial 15 per cent to close to 10 to 11 per cent. It is clearly visible that dollar funding disruptions typically emerged at the beginning of the recession periods, but the 3-month EUR-USD basis swap remained negative throughout. 


\section{Figure 4}

Values of market variables included in the model

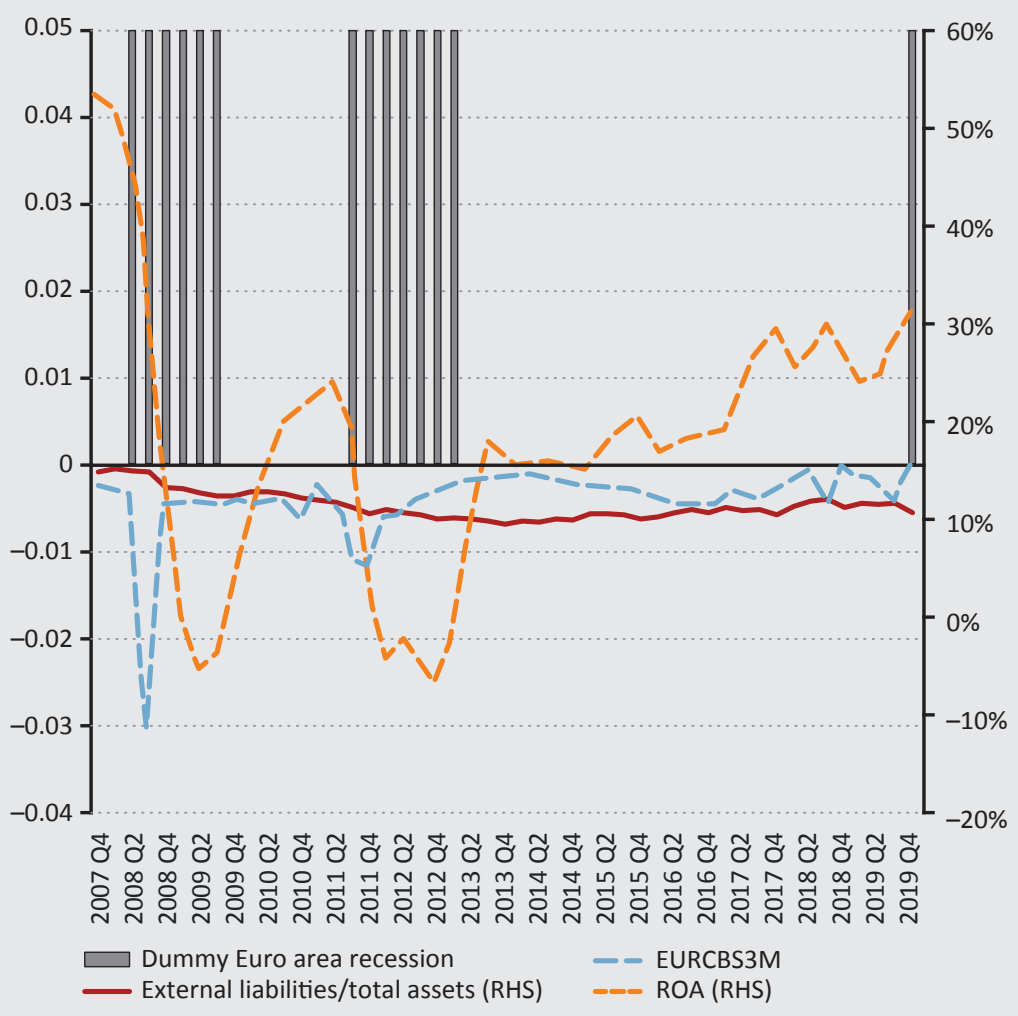

Source: Plotted based on Refinitiv Eikon, European Commission and ECB

\subsection{Methodology}

Vector autoregressive (VAR) processes characterise the data generation process of a smaller amount of time series variable, where a priori endogeneity is assumed for each variable and their dynamics are taken into account. This procedure records the dynamic interactions of a set of time series variables of $N$ number: $y_{t}=\left(y_{1 t}, \ldots, y_{K t}\right)^{\prime}$. The basic VAR model can be described in the following reduced form (2) based on Lütkepohl - Kratzig (2004):

$$
y_{t}=A_{1} y_{t-1}+\cdots+A_{p} y_{t-p}+\varepsilon_{t}
$$

where $y_{t}$ is the $(N x 1)$ vector containing the model variables, $F_{i}$ is a matrix containing $(N \times N)$ autoregression coefficients, and $\varepsilon_{t}=\left(u_{1 t}, \ldots, u_{K t}\right)^{\prime}$ is the unobserved error term, which is a vector with (Nx1) Gaussian distribution containing a discrete representation white noise process and $\varepsilon_{t} \sim\left(0, E\left(u_{t}, u_{t}{ }^{\prime}\right)\right)$ is a positive definite covariance matrix. Weak stationarity is expected for input variables, while the 
error terms of the equation lack autocorrelation (Ljung-Box $p>0.05$ for each time lag or $1.85<$ Durbin-Watson < 2.15) and normal distribution (Jarque-Bera-test $p>0.05)$ is desirable.

When writing equation (2), several restrictions of the parameters are conceivable: in the case of Cholesky's writing, the short-term restriction can be used to describe the sequence of shocks, while with Blanchard-Quah's long-term restriction, the appearance of the shock can be described. To do this, we first need to introduce the structural (3) version of the reduced VAR form (with a time lag $p$ and three variables with structural coefficients $A$ and $A^{s}$ ):

$A y_{t}=A_{1}^{S} y_{t-1}+\cdots+A_{p}^{S} y_{t-p}+B u_{t}$, where $\varepsilon_{t}=A^{-1} B u_{t}$ and $S=A^{-1} B$.

In Cholesky's restriction (4), we assume that the value of certain coefficients is zero and $u_{1 t}$ immediately affects the other variables concurrently, while $u_{2 t}$ affects only variables 2 and 3 concurrently, and $u_{3 t}$ only the third:

$$
\varepsilon_{t}=S u_{t}=\left[\begin{array}{ccc}
s_{11} & 0 & 0 \\
s_{21} & s_{22} & 0 \\
s_{31} & s_{32} & s_{33}
\end{array}\right]\left[\begin{array}{l}
u_{1 t} \\
u_{2 t} \\
u_{3 t}
\end{array}\right]
$$

By contrast, in the long-term restriction of Blanchard - Quah (1989) (5), the shock is searched for only in the row of the F-matrix where the variable appears, and the cumulative long-term effect of the shock is zero and $\Psi$ the long-term multiplier $(F=\Psi S)$ is:

$\left(I-A_{1}-\cdots-A_{p}\right)^{-1} \varepsilon_{t}=\Psi \varepsilon_{t}=F u_{t}$ and $F=\left[\begin{array}{ccc}f_{11} & 0 & 0 \\ f_{21} & f_{22} & 0 \\ f_{31} & f_{32} & f_{33}\end{array}\right]$, while $S=\left[\begin{array}{lll}s_{11} & s_{12} & s_{13} \\ s_{21} & s_{22} & s_{23} \\ s_{31} & s_{32} & s_{33}\end{array}\right]$.

The structure of the F-matrix describing long-term effects (Table 1) when using the Eviews programme determined the order of the variables loaded into the VAR model ${ }^{19}$ at the same time - given that there will be a shock that will affect each variable, and the variable at the end of the sequence will be the one that only affects itself. Shocks from the dollar liquidity-providing tenders of the ECB as the leading central bank should affect the other variables included in the model, otherwise their effectiveness would be questionable. However, in the long run the shocks of the EUR-USD basis swap rate can no longer have a significant effect on the development of the amount lent $\left(f_{12}=0\right)$. For the shocks of the banking system's exposure outside the euro area, the swap rate and the ECB's liquidity lending can be interpreted as externalities, therefore their long-term impact can be considered

${ }^{19}$ In our case this means running the following script:

var var1.Is 15 dkih_usd deurcbs3m dez_kivuli_forras dlsfxdroa @ cdummy_ez_recdummy_outlier 
zero $\left(f_{13}=0, f_{23}=0\right)$. The change in the asset-side structure of the central bank's balance sheet maps the use of the full, conventional and non-conventional toolbox (excluding possible changes in leverage), but by its nature this cannot describe either the development of dollar liquidity, the swap rate or the external exposure of the banking system $\left(f_{14}=0, f_{24}=0, f_{34}=0\right)$. In the normal course of business, the goal is not to consider the banking system's return on assets $(R O A)$ in the long run in terms of conducting monetary policy or market financing conditions $\left(f_{15}=0, f_{25}=0\right.$, $f_{35}=0, f_{45}=0$ ).

\section{Table 1}

Structure of F-matrix containing long-term effects

\begin{tabular}{|c|c|c|c|c|c|c|}
\hline & \multicolumn{5}{|c|}{ shock } \\
\hline & & $\Delta \frac{K_{U S D, t}}{\sum K_{U S D}}$ & $\Delta \frac{b S_{3 M, \frac{E U R}{U S D}}}{100}$ & $\Delta \frac{L_{n E Z, t}}{T L_{t}}$ & $\Delta \frac{L_{t}+S_{t}}{F X_{t}}$ & $\Delta R O A_{t}$ \\
\hline \multirow{5}{*}{$\begin{array}{l}\frac{0}{0} \\
\frac{\pi}{\frac{\pi}{2}} \\
\frac{10}{>}\end{array}$} & $\Delta \frac{K_{U S D, t}}{\sum K_{U S D}}$ & $f_{11}$ & 0 & 0 & 0 & 0 \\
\hline & $\Delta \frac{b S_{3 M, \frac{E U R}{U S D}}}{100}$ & $f_{21}$ & $f_{22}$ & 0 & 0 & 0 \\
\hline & $\Delta \frac{L_{n E Z, t}}{T L_{t}}$ & $f_{31}$ & $f_{32}$ & $f_{33}$ & 0 & 0 \\
\hline & $\Delta \frac{L_{t}+S_{t}}{F X_{t}}$ & $f_{41}$ & $f_{42}$ & $f_{43}$ & $f_{44}$ & 0 \\
\hline & $\Delta R O A_{t}$ & $f_{51}$ & $f_{52}$ & $f_{53}$ & $f_{45}$ & $f_{55}$ \\
\hline
\end{tabular}

Impulse response functions are the effect of a unit shock on a given model variable, where the shock of variable $i$ to variable $j$, ceteris paribus, is simply the order of the elements in row $i$ and column $j$, in the $C_{k}=\frac{d y_{t}}{d \varepsilon_{t-k}}$ matrix.

The variance decomposition makes it possible to determine which shocks are decisive in the short- and long-term evolution of certain variables, i.e. the proportion of the uncertainty of variable $i$ that can be attributed to the $j^{\text {th }}$ shock after period $h$ :

$\mathcal{V} D_{i, j, h}=\frac{\sum_{k=0}^{h}\left(k c_{i, j}\right)^{2}}{\sum_{k=0}^{h} \sum_{l=1}^{n}\left(k c_{i, l}\right)^{2}}$.

\section{Results}

The results of the calculations based on the theoretical model are presented in three steps: first we present the basic statistics of the logarithmic changes of the input variables, then we present the equations obtained from VAR fittings and the results of tests examining non-autocorrelation and the normal distribution of error terms. Finally, the resulting impulse response functions and variance decompositions are plotted. 


\subsection{Basic statistics}

As can be seen from Table 2, only stationary variables were included in the VAR model, which in some cases proved to be of normal distribution. Dummy variables are designed to compensate for the outstanding kurtosis of lent dollar liquidity and the foreign currency basis swap.

\begin{tabular}{|c|c|c|c|c|c|c|c|c|}
\hline \multicolumn{9}{|c|}{$\begin{array}{l}\text { Table } 2 \\
\text { Basic statistics of input variables }\end{array}$} \\
\hline Test & \multicolumn{4}{|c|}{ Central momentums } & \multirow{2}{*}{$\begin{array}{c}\begin{array}{c}\text { Normal } \\
\text { distribution }\end{array} \\
\text { Jarque- } \\
\text { Bera }(p)\end{array}$} & \multirow{2}{*}{$\begin{array}{c}\text { Auto- } \\
\text { correlation } \\
\begin{array}{c}\text { Ljung-Box } \\
\text { (p) }\end{array}\end{array}$} & \multirow{2}{*}{$\begin{array}{c}\text { Hetero- } \\
\text { scedasticity }\end{array}$} & \multirow{2}{*}{$\begin{array}{l}\text { Unit-root } \\
\text { ADF (p) }\end{array}$} \\
\hline variable & average & skewness & peakedness & kurtosis & & & & \\
\hline$\Delta \frac{K_{U S D, t}}{\sum K_{U S D}}$ & 0.0000 & 0.0468 & 1.8711 & 20.8573 & 0.0000 & 0.4482 & 0.6911 & 0.0000 \\
\hline$\Delta \frac{L_{n E Z, t}}{T L_{t}}$ & -0.0049 & 0.0507 & 0.0019 & 2.6201 & 0.7937 & 0.2202 & 0.1994 & 0.0039 \\
\hline$\triangle R O A_{t}$ & -0.0044 & 0.0618 & -1.2076 & 5.7197 & 0.0000 & 0.0000 & 0.0014 & 0.0022 \\
\hline$\Delta \frac{L_{t}+S_{t}}{F X_{t}}$ & 0.0494 & 0.2606 & 0.0852 & 2.3245 & 0.5453 & 0.0157 & 0.0232 & 0.0001 \\
\hline$\Delta \frac{b S_{3 M, \frac{E U R}{U S D}}}{100}$ & 0.0035 & 0.5821 & -0.2699 & 18.5860 & 0.0000 & 0.0044 & 0.3041 & 0.0000 \\
\hline
\end{tabular}

\subsection{VAR model}

The time lag of the VAR model was determined partly based on the information criteria (Schwarz IC recommended a 5-quarter time lag) and partly based on the normal distribution and non-autocorrelation of the error terms. AIC and HQ criteria suggested a 6-quarter time lag, but those models did not have normally distributed error terms, therefore we opted for the 5-quarter time lag model.

As shown in Table 3, the LM-test testing autocorrelation shows that the error terms of the VAR equation meet the requirements for non-autocorrelation, and their distribution is also normal based on the Jarque-Bera test. The $\mathrm{S}$ and F-matrices of the structural model are contained in Table 4 of the Annex. 


\begin{tabular}{|c|c|c|c|}
\hline \multicolumn{4}{|c|}{$\begin{array}{l}\text { Table } 3 \\
\text { Examination of error terms of the two VAR equations: non-autocorrelation and } \\
\text { normal distribution }\end{array}$} \\
\hline & & time lag & $p$-value \\
\hline \multirow{12}{*}{ LM-test } & \multirow{6}{*}{ h-time lag } & 1 & 0.3037 \\
\hline & & 2 & 0.9204 \\
\hline & & 3 & 0.7095 \\
\hline & & 4 & 0.8209 \\
\hline & & 5 & 0.2207 \\
\hline & & 6 & 0.8137 \\
\hline & \multirow{6}{*}{ 1:h time lag } & 1 & 0.3037 \\
\hline & & 2 & 0.4463 \\
\hline & & 3 & NA \\
\hline & & 4 & NA \\
\hline & & 5 & NA \\
\hline & & 6 & NA \\
\hline \multicolumn{2}{|c|}{ Jarque-Bera } & Joint & 0.7959 \\
\hline
\end{tabular}

Note: NA: No data available

Source: Plotted with Eviews 11 software

\subsection{Impulse response functions and variance decomposition}

The cumulative impulse response functions calculated using the long-term restrictions used in the structural VAR model (Figure 5) show a negative effect of the change in non-euro area liabilities in commercial bank balance sheets losing significance after 5 quarters, in addition to the ongoing self-stimulating change in dollar lending - the increase in the ratio was accompanied by declining use of ECB's dollar auctions. That is, in such cases, the banking sector was able to finance itself on market basis. Although the declining value of foreign currency basis swaps suggests an increase in dollar market tensions, in the first quarter the lending had a counter-intuitive sign ${ }^{20}$. An increase in return on assets (ROA) over 3 quarters will result in a decrease in tendered dollar liquidity. The expansion of non-conventional lending and securities purchase programs $((L+S) / F X)$ is accompanied by a decline in dollar liquidity placement in addition to the 4-quarter time lag, suggesting that dollar liquidity placements had already been over when securities market programs rose. Based on the results obtained, the assumptions of the model can only be interpreted in the long run to a significant extent with a time lag of a few quarters. The VAR model was also fitted with several alignments of the F-matrix, but qualitatively similar results to those above were obtained.

${ }^{20}$ The variable retained this property even with multiple writings of the structural F-matrix, so this result can be considered robust. 


\section{Figure 5 \\ Cumulated impulse response functions of the structural VAR model}

The response of allocated USD on the shock of the allocated USD

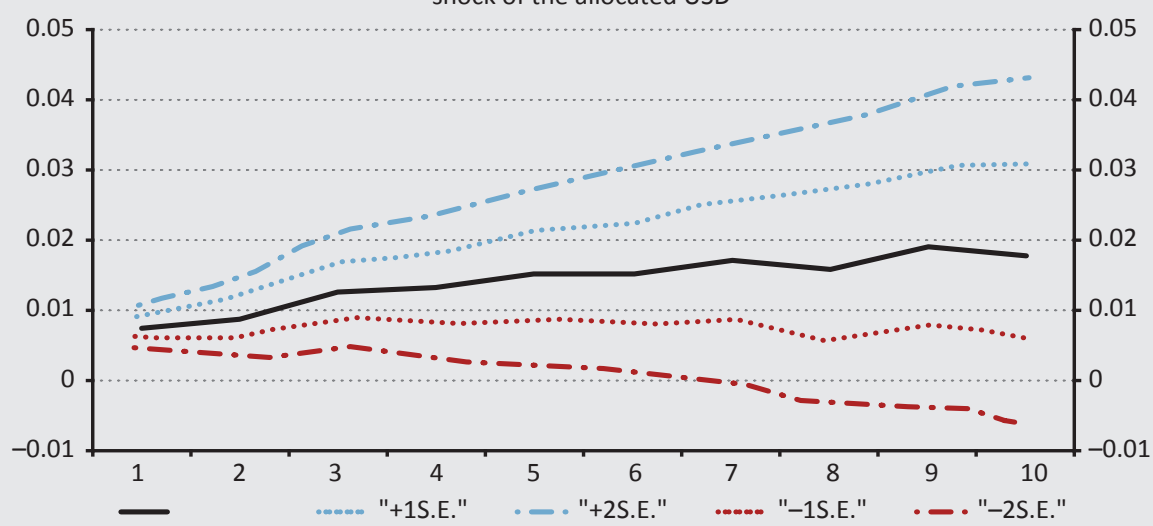

The response of allocated USD on the

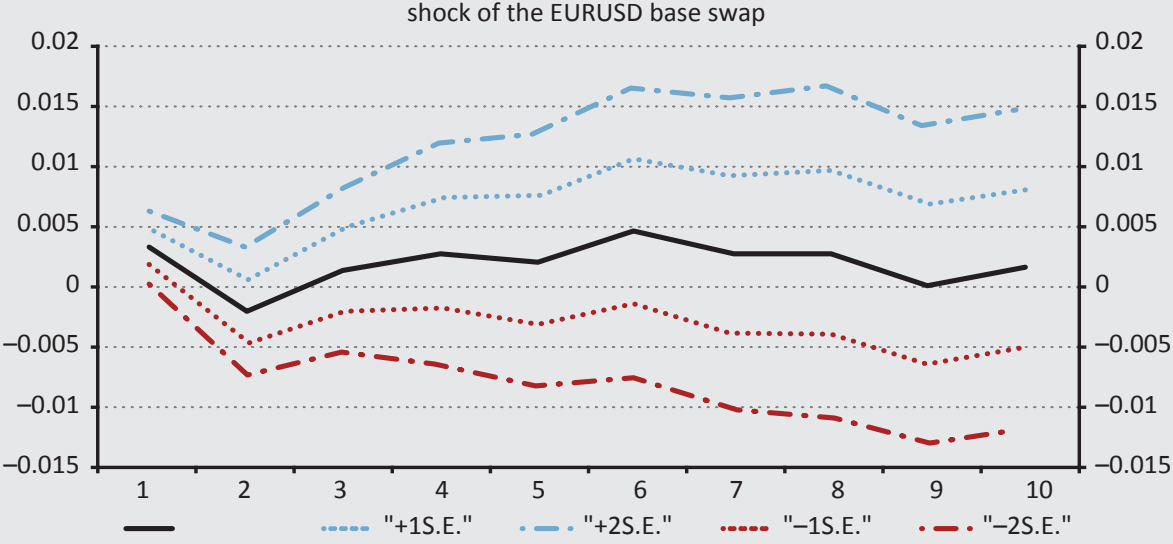

The response of allocated USD on the shock of the external liabilities

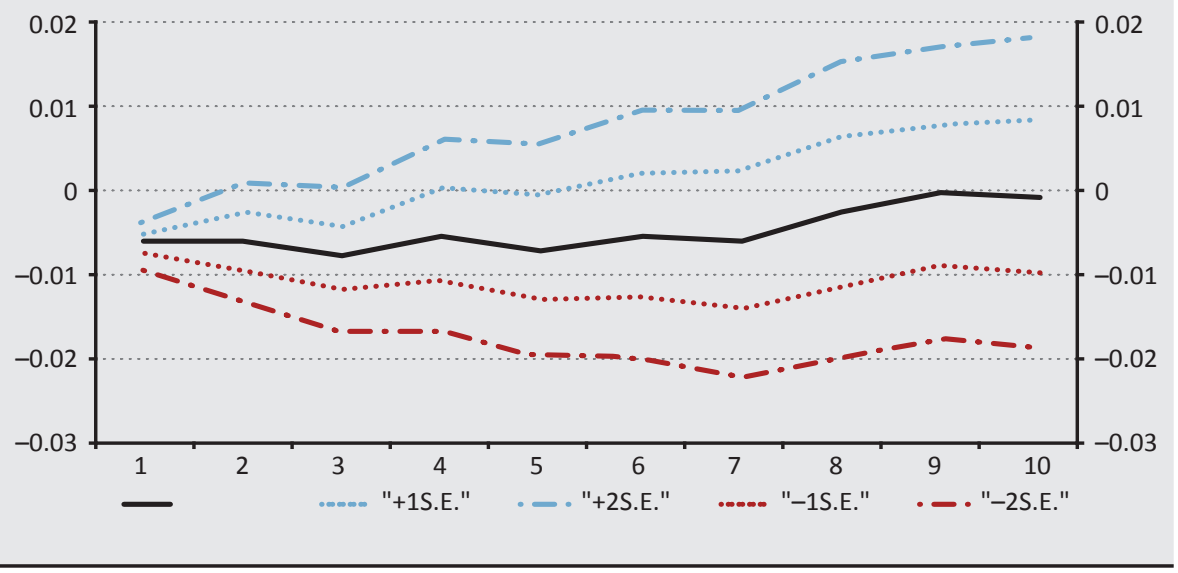




\section{Figure 5 \\ Cumulated impulse response functions of the structural VAR model}

The response of allocated USD on the shock of the $(L+S) / F X$ ratio

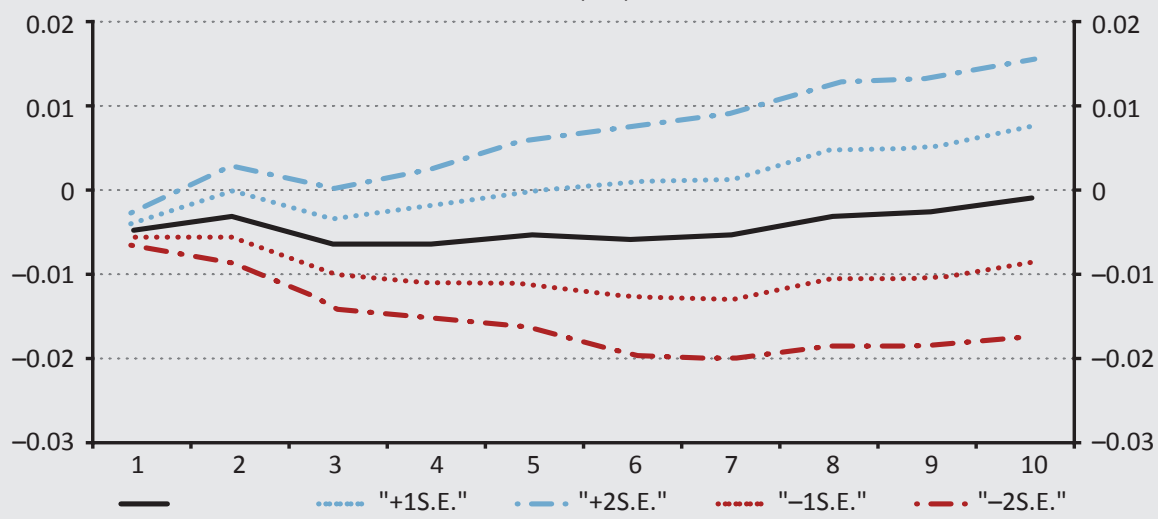

The response of allocated USD on the shock of the ROA

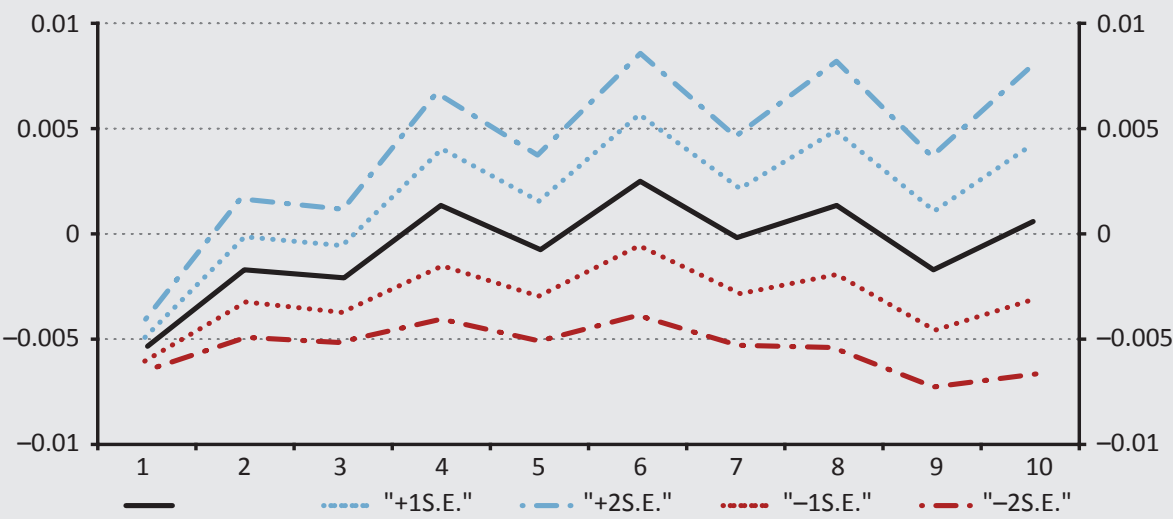

Note: Black solid lines indicate impulse response functions, while $68 \%$ ( \pm 1 S.E.) and $95 \%$ ( \pm 2 S.E.) confidence intervals based on Albrizio et al. (2020).

Source: Plotted with Eviews11 software 
Based on the variance decompositions performed (Figure 6), the variance of the change in dollar liquidity provided by the ECB has been affected by the variables in the model for several quarters, to almost 70 per cent. The weight of non-euroarea funds declines from an initial 27 per cent to close to 20 per cent in the second quarter, which is similar to the weight of changes in the basis swap and ROA. Meanwhile, the importance of the central bank's balance sheet structure remained between 10 and 15 per cent throughout.

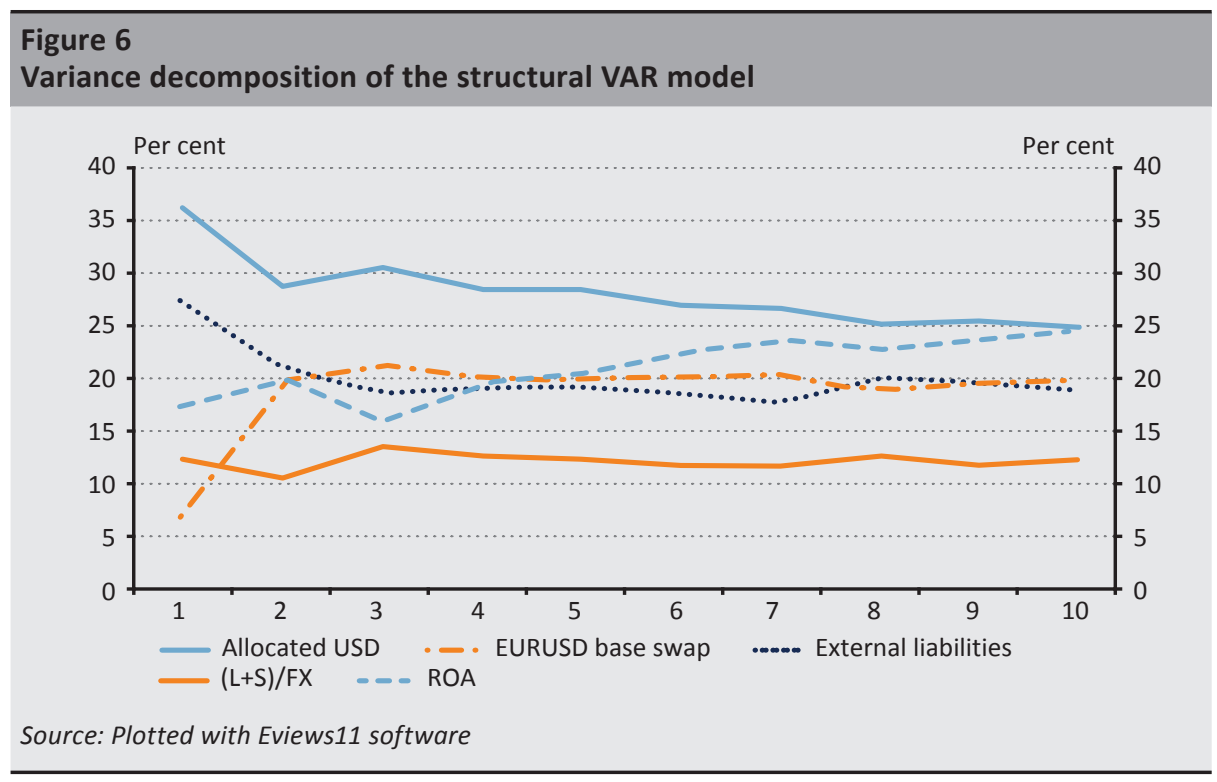

\section{Summary}

In the course of our work, we first reviewed the agreements that led to each leading central bank providing one another with foreign currency liquidity after December 2007 in order to fulfil their role as the "last resort" in supplying adequate foreign currency liquidity. We then outlined our theoretical model and described the data included in the study. We analysed the statements made in the model using structural vector autoregression that examines long-term correlations.

Overall, the model we have written has been validated with euro area credit institutions turning to the ECB for dollar-denominated foreign currency liquidity mainly when it has become difficult to raise funds outside the euro area, their return on asset ratios have declined, or tensions have emerged in the dollar market. Parallel to this, the impact of euro-denominated lending and securities accumulation was also felt. This means we can also confirm the theoretical expectations formulated in connection with the theoretical model, according to which, due to market 
disturbances and the freezing of traditional channels of international capital flows, credit institutions really needed foreign currency funds available through swap lines between central banks.

It seems that this market failure was not limited exclusively to the period of the 2007-2009 global financial crisis, but the effects can also be revealed in a sample describing the last 12 years. This is suggested by the fact that although leading central banks have made several attempts to suspend interbank swap lines, citing the temporary drying-up of credit institutions' foreign currency liquidity needs, these programs had to be relaunched several times and today they are now largely part of normal business operations. This also well illustrates the process where the philosophy and toolbox of "unconventional" monetary policy, initially considered temporary, have now become dominant in the operation of the world's central banks.

\section{References}

Ács, A. (2011): A likviditás dimenziói (Dimensions of Liquidity). Hitelintézeti Szemle, 10(3): 241-261.

Aizenman, J. - Cheung, Y-W. - Qian, X. (2020): The currency composition of international reserves, demand for international reserves, and global safe assets. Journal of International Money and Finance, 102(April): 102120. https://doi.org/10.1016/j.jimonfin.2019.102120

Albrizio, S. - Choi, S. - Furceri, D. - Yoon, C. (2020): International bank lending channel of monetary policy. Journal of International Money and Finance, 102(April): 102124. https:// doi.org/10.1016/j.jimonfin.2019.102124

Aldasoro, I. - Ehlers, T. - Eren, E. (2019): Global Banks, Dollar Funding, and Regulation. BIS Working Papers No 708, Bank of International Settlements, May. https://doi.org/10.2139/ ssrn.3368973

Allen, F. - Babus, A. (2009): Networks in Finance. In: Kleindorfer, P. - Wind, J. - Gunther, R.E. (eds.): Network Challenge, The Strategy, Profit, and Risk in an Interlinked World, Pearson Prentice Hall, pp. 367-382. https://doi.org/10.2139/ssrn.1094883

Allen, W.A. - Moessner, R. (2010): Central bank co-operation and international liquidity in the financial crisis of 2008-9. BIS Working Papers No 310, Bank of International Settlements. https://doi.org/10.2139/ssrn.1631791

Alvarez, I. - Casavecchia, F. - De Luca, M. - Duering, A. - Eser, F. - Helmus, C. - Hemous, C. (2017): The Use of the Eurosystem's Monetary Policy Instruments and Operational Framework since 2012. ECB Occasional Paper 188, European Central Bank. https://doi. org/10.2866/112727 
Ananda, K. - Gaib, P. - Marsilid, M. (2012): Rollover risk, network structure and systemic financial crises. Journal of Economic Dynamics and Control, 36(8): 1088-1100. https:// doi.org/10.1016/j.jedc.2012.03.005

Antal, J. - Gereben, Á. (2011): Foreign reserve strategies for emerging economies - before and after the crisis. MNB Bulletin, 2011(1): 7-19. https://www.mnb.hu/letoltes/antalgereben-eng.pdf

Avdjiev. S. - Subelyte, A. - Takáts, E. (2016): The ECB's QE and euro cross-border bank lending. BIS Quarterly Review, Bank for International Settlements, September. https://www.bis. org/publ/qtrpdf/r_qt1609h.htm. Downloaded: 10 March 2020.

Baker, C. (2013): The Federal Reserve's Use of International Swap Lines. Arizona Law Review, 55: 603-654. https://doi.org/10.2139/ssrn.2226708

Banai, Á. - Kollarik, A. - Szabó-Solticzky, A. (2015): Topology of the foreign currency/ forint swap market. Financial and Economic Review, 14(2): 128-157. https://enhitelintezetiszemle.mnb.hu/letoltes/5-banai-kollarik-szabo-en.pdf

Berlinger, E. - Michaletzky, M. - Szenes, M. (2011): A fedezetlen bankközi forintpiac hálózati dinamikájának vizsgálata a likviditási válság elött és után (Examination of the network dynamics of the uncovered interbank forint market before the liquidity crisis and after). Közgazdasági Szemle (Economic Review), 58(March): 229-252.

BIS (2011): Global liquidity - concept, measurement and policy implications. BIS CGFS Publications No 45, Bank of International Settlements, November. https://www.bis.org/ publ/cgfs45.pdf. Downloaded: 10 March 2020.

Blanchard, O.J. - Quah, D. (1989): The Dynamic Effects of Aggregate Demand and Supply Disturbances. The American Economic Review, 79(4): 655-673.

Bordo, M.D. - Humpage, O.F. - Schwartz, A.J. (2015): The Evolution of the Federal Reserve Swap Lines since 1962. IMF Economic Review, 63(2): 353-372. https://doi.org/10.1057/ imfer.2015.11

Brophy, T. - Herrala, N. - Jurado, R. - Katsalirou, I. - Le Quéau, L. - Lizarazo, C. - O’Donnell, S. (2019): Role of cross currency swap markets in funding and investment decisions. ECB Occasional Paper Series No 228, European Central Bank, August. https://www.ecb.europa. eu//pub/pdf/scpops/ecb.op228 bb3e50120a.en.pdf. Download date: 10 March 2020.

Csávás, Cs. - Szabó, R. (2010): A forint/deviza FX-swap szpredek mozgatórugói a Lehman-csőd utáni idöszakban (Determinants of Hungarian forint FX swap spreads after the Lehman crisis). Hitelintézeti Szemle, 9(6): 566-580.

Destais, C. (2016): Central Bank Currency Swaps and the International Monetary System. Emerging Markets Finance and Trade, 52(10): 2253-2266. https://doi. org/10.1080/1540496X.2016.1185710 
ECB (2008): EU Banking Structures. European Central Bank, October. https://www.ecb. europa.eu/pub/pdf/other/eubankingstructures2008en.pdf. Downloaded: 10 March 2020.

ECB (2019): The international role of the euro. European Central Bank, June. https://www. ecb.europa.eu/pub/ire/html/ecb.ire201906 f0da2b823e.en.html. Downloaded: 2 April 2020.

Engelberth, I. - Sági, J. (2017): Role and objectives of the New Silk Road initiative. Foreign Policy Review, 16(3): 85-104.

Frankel, J. (2011): Monetary Policy in Emerging Markets. In: Friedman, B.M. - Woodford, M. (eds.): Handbook of Monetary Economics. Elsevier, pp. 1441-1499.

Ivashina, V. - Scharfstein, D S. - Stein, J.C. (2015): Dollar Funding and the Lending Behavior of Global Banks. Quarterly Journal of Economics, 130(3): 1241-1281. https://doi. org/10.1093/qje/qjv017

Kick, T. - Koetter, M. - Storz, M. (2018): Cross-border transmission of emergency liquidity, Journal of Banking and Finance, 113: 105300. https://doi.org/10.1016/j. jbankfin.2018.02.006

Kiss, G.D. - Ampah, I.K. (2018): Macroeconomic Volatility and Capital Flights in Sub-Saharan Africa: A Dynamic Panel Estimation of some Selected HIPC Countries. Mediterranean Journal of Social Sciences, 9(5): 165-176. https://doi.org/10.2478/mjss-2018-0148

Lütkepohl, H. - Kratzig, M. (2004): Applied Time Series Econometrics. Cambridge University Press, Cambridge. https://doi.org/10.1017/СBO9780511606885

Madura, J. (2008): International Financial Management. Thompson.

Mák, I. - Páles, J. (2009): The role of the FX swap market in the Hungarian financial system. MNB Bulletin, 2009(5): 24-34. https://www.mnb.hu/letoltes/mak-pales-en.pdf

Obstfeld, M. - Shambaugh J. C. - Taylor, A. M. (2009): Financial Instability, Reserves, and Central Bank Swap Lines in the Panic of 2008. American Economic Review, 99(2): 480-486. https://doi.org/10.1257/aer.99.2.480

Páles, J. - Kuti, Zs. - Csávás, Cs. (2010): The role of currency swaps in the domestic banking system and the functioning the swap market during the crisis. MNB Occasional Papers 90, Magyar Nemzeti Bank. https://www.mnb.hu/letoltes/op-90.pdf

Pelle, A. - Végh, M. (2019): Hogyan változott az euróövezet a kezdetek óta? (How has the Eurozone Changed Since its Inception?) Pénzügyi Szemle (Public Finance Quarterly), 64(1): 127-145.

Seghezza, E. (2018): Can swap line arrangements help solve the Triffin dilemma? How? The World Economy, 41(10): 2691-2708. http://doi.org/10.1111/twec.12669

Takáts, E. - Temesvary, J. (2020): The currency dimension of the bank lending channel in international monetary transmission. Journal of International Economics, 125(7): 103309. http://doi.org/10.1016/j.jinteco.2020.103309 


\section{Annex}

Maximum likelihood via Newton-Raphson (analytic derivatives)

Model: $\mathrm{e}=$ Phi*Fu where $\mathrm{E}\left[\mathrm{uu}^{\prime}\right]=\mathrm{I}$

\begin{tabular}{|c|c|c|c|c|}
\hline $\begin{array}{l}\text { Table } 4 \\
\text { Result of str }\end{array}$ & VAR-estim & & & \\
\hline \multicolumn{5}{|l|}{$F=$} \\
\hline$C(1)$ & 0 & 0 & 0 & 0 \\
\hline$C(2)$ & $C(6)$ & 0 & 0 & 0 \\
\hline$C(3)$ & $C(7)$ & $C(10)$ & 0 & 0 \\
\hline$C(4)$ & $C(8)$ & $C(11)$ & $C(13)$ & 0 \\
\hline \multirow[t]{2}{*}{$C(5)$} & $C(9)$ & $C(12)$ & $C(14)$ & $C(15)$ \\
\hline & Coefficient & Std. Error & z-Statistic & Prob. \\
\hline$C(1)$ & 0.024857 & 0.002650 & 9.380826 & 0.0000 \\
\hline$C(2)$ & 0.011785 & 0.010943 & 1.076922 & 0.2815 \\
\hline$C(3)$ & 0.019235 & 0.004873 & 3.947205 & 0.0001 \\
\hline$C(4)$ & 0.625060 & 0.097028 & 6.442088 & 0.0000 \\
\hline$C(5)$ & 0.005552 & 0.003701 & 1.500050 & 0.1336 \\
\hline$C(6)$ & 0.072107 & 0.007687 & 9.380829 & 0.0000 \\
\hline$c(7)$ & -0.022397 & 0.003721 & -6.019773 & 0.0000 \\
\hline$C(8)$ & -0.052148 & 0.070311 & -0.741673 & 0.4583 \\
\hline$C(9)$ & 0.018413 & 0.003082 & 5.975096 & 0.0000 \\
\hline$C(10)$ & 0.018928 & 0.002018 & 9.380830 & 0.0000 \\
\hline$C(11)$ & 0.335420 & 0.060285 & 5.563905 & 0.0000 \\
\hline$C(12)$ & -0.011781 & 0.002017 & -5.842328 & 0.0000 \\
\hline$C(13)$ & 0.321955 & 0.034321 & 9.380830 & 0.0000 \\
\hline$C(14)$ & -0.004081 & 0.001517 & -2.690743 & 0.0071 \\
\hline$C(15)$ & 0.009637 & 0.001027 & 9.380830 & 0.0000 \\
\hline Log likelihood & 362.9767 & & & \\
\hline \multicolumn{5}{|c|}{ Estimated S matrix: } \\
\hline 0,007579 & 0.003314 & -0.006604 & -0.004399 & -0.005283 \\
\hline$-0,037969$ & 0.160091 & -0.082201 & -0.094112 & 0.026249 \\
\hline 0,012097 & -0.015354 & 0.003329 & -0.027091 & 0.002315 \\
\hline 0,119286 & 0.068561 & 0.135037 & 0.081387 & 0.003683 \\
\hline 0,009802 & 0.013461 & -0.011657 & -0.000911 & 0.010490 \\
\hline \multicolumn{5}{|c|}{ Estimated F matrix: } \\
\hline 0,024857 & 0.000000 & 0.000000 & 0.000000 & 0.000000 \\
\hline 0,011785 & 0.072107 & 0.000000 & 0.000000 & 0.000000 \\
\hline 0,019235 & -0.022397 & 0.018928 & 0.000000 & 0.000000 \\
\hline 0,625060 & -0.052148 & 0.335420 & 0.321955 & 0.000000 \\
\hline 0,005552 & 0.018413 & -0.011781 & -0.004081 & 0.009637 \\
\hline
\end{tabular}

